\title{
Jogos eletrônicos e cinema: hibridação de maneiras de representar
}

\author{
Bruno Galiza Gama \\ LYRA
}

\section{Resumo}

Esta investigação observa os ambientes do jogo eletrônico e do cinema como ambientes essencialmente de representação, com a manipulação de signos visuais reproduzindo e gerando sentidos. No cinema as representações estão relacionadas ao arranjo de signos pré-existentes de maneira significativa, ao passo que no ambiente do jogo eletrônico a construção da significação dá-se inclusive na construção formal dos objetos; nota-se um tipo de hibridação em que um meio beneficia-se do outro por meio da apropriação de tradições estabelecidas (de uso de signos, gêneros narrativos, composição formal), ou por meio da absorção do ritmo narrativo, estando aí envolvido o papel desempenhado pelo observador no circuito da promoção do significado. Os objetos da pesquisa relacionam-se à construção de significado na área do gênero narrativo através da identificação de características estruturais e significativas comuns em um e no outro meio, estando assim observada a dita hibridação das linguagens. Gêneros pressupõem elementos visuais que endereçam a obra a públicos que possuem expectativas no que tange a presença de determinados elementos que identifiquem o objeto como passível desta classificação. A proposta envolve análise de peças de um e de outro meio que tragam em si aspectos formais e significantes de um mesmo gênero, que serão confrontados em busca desta intersecção que permita o tipo de leitura proposto pelo emissor, considerando-se aí as diferenças nas maneiras de olhar e na conformação destes objetos no âmbito da cultura. A identificação de elementos visuais comuns a estes (e a outros) meios, que permitam leituras e significações específicas, permitirá sua posterior aplicação num jogo eletrônico, observando assim sua utilização em prol de uma poética que pressuponha um objeto conformado em determinado gênero.

Palavras-chave: Cinema, jogos eletrônicos, poéticas visuais. 